\title{
Identification of Individual Powdery Mildew Fungi Infecting Leaves and Direct Detection of Gene Expression by Single Conidium Polymerase Chain Reaction
}

\author{
Yoshinori Matsuda, Takeshi Sameshima, Nobuyuki Moriura, Kanako Inoue, Teruo Nonomura, Koji Kakutani, Hiroaki \\ Nishimura, Shin-ichi Kusakari, Susumu Takamatsu, and Hideyoshi Toyoda
}

First to fifth and tenth authors: Laboratory of Plant Pathology and Biotechnology, Faculty of Agriculture, Kinki University, Nara 631-8505, Japan; sixth author: Pharmaceutical Research and Technology Institute, Kinki University, Osaka 577-8502, Japan; seventh author: Research Institute, Kagome Company, Ltd., Tochigi 329-2762, Japan; eighth author: Agricultural, Food and Environmental Sciences Research Center of Osaka Prefecture, Osaka, 583-0862, Japan; and ninth author: Faculty of Bioresources, Mie University, Mie 514-8507, Japan.

Accepted for publication 19 May 2005.

\begin{abstract}
Matsuda, Y., Sameshima, T., Moriura, N., Inoue, K., Nonomura, T., Kakutani, K., Nishimura, H., Kusakari, S., Takamatsu, S., and Toyoda, H. 2005. Identification of individual powdery mildew fungi infecting leaves and direct detection of gene expression by single conidium polymerase chain reaction. Phytopathology 95:1137-1143.

Greenhouse-grown tomato seedlings were inoculated naturally with two genera of powdery mildew conidia forming appressorial germ tubes that could not be differentiated by length alone. For direct identification, single germinated conidia were removed from leaves by means of a glass pipette linked to the manipulator of a high-fidelity digital microscope. This microscope enabled in vivo observation of the fungi without leaf decoloration or fungal staining. The isolated conidia were subjected to PCR amplification of the 5.8S rDNA and its adjacent internal transcribed

spacer sequences followed by nested PCR to attain sensitivity high enough to amplify target nucleotide sequences (PCR/nested PCR). Target sequences from the conidia were completely coincident with those of the pathogen Oidium neolycopersici or Erysiphe trifolii (syn. Microsphaera trifolii), which is nonpathogenic on tomato. Using RT-PCR/nested PCR or multiplex RT-PCR/nested PCR, it was possible to amplify transcripts expressed in single conidia. Conidia at pre- and postgermination stages were removed individually from tomato leaves, and two powdery mildew genes were monitored. The results indicated that the $\beta$-tubulin homolog TUB2-ol was expressed at pre- and postgermination stages and the cutinase homolog CUT1-ol was only expressed postgermination. Combining digital microscopic micromanipulation and two-step PCR amplification is thus useful for investigation of individual propagules on the surface of plants.
\end{abstract}

Conidia of powdery mildew fungi are wind-dispersed from susceptible hosts to other plants (4). Conidia germinate to form appressoria on both host and nonhost plant leaves and then attempt to invade and form haustoria for establishing infection and disease. Plants react chemically and cytologically to the presence of the powdery mildew fungi (1). Nonhost plants suppress haustorial formation by hypersensitive reaction in invaded epidermal cells of leaves, inhibiting subsequent mycelial development and production of progeny conidia (1). These leaves appear healthy to the unaided eye, without visible signs of the fungi on the leaf surface. Studying plant response to a powdery mildew fungus may be complicated if leaves have concomitant cytological responses against attack by nonpathogenic powdery mildews that are indistinguishable from the study fungus. In our preliminary observations, powdery mildew conidia were detected on noninoculated tomato leaves, especially when plants were grown in a greenhouse where natural infection by undesired powdery mildew fungi cannot be completely prevented. The appressoria formed on the leaves were frequently similar to those of Oidium neolycopersici, the pathogen of tomato powdery mildew (11). This complicated the analysis of initial events in the interactions between the plant and fungus at the prehaustorial stage of the powdery mildew infection. In fact, some conidia failed to form

Corresponding author: H. Toyoda, E-mail address: toyoda@nara.kindai.ac.jp

DOI: 10.1094/PHYTO-95-1137

(C) 2005 The American Phytopathological Society haustoria as the result of hypersensitive cell death in fungalinfected epidermal cells of tomato leaves after inoculation with the conidia of $O$. neolycopersici (23). Conventional morphological and molecular methods, however, were not adequate to clarify whether the conidia responsible for the hypersensitive response were those of $O$. neolycopersici. To solve this problem, we worked to develop an efficient method for identifying individual fungal propagules on leaves.

An initial approach was to use a microinjection technique, which was applied to directly introduce labeled hybridization probes into the powdery mildew pathogen infecting the host while observing with a light microscope (15). Although this technique enabled the in situ hybridization detection of rRNAs in single propagules on the host, the possible application was limited to the pathogen on light-permeable tissues such as barley coleoptile epidermis (29), and the hybridization detection was not sensitive enough to distinguish individual propagules from species that had small differences in the nucleotide sequences of rRNAs. In the present study, we explored the use of a technique to observe and collect single conidia from the leaves using a micropipette and a high-fidelity digital microscope. The pathogen was then identified by sequence-selective nested polymerase chain reaction (PCR) analysis of the 5.8S rRNA gene (rDNA) and its flanking internal transcribed spacer (ITS) regions (entire 5.8S rDNA/ITS region) amplified by nested PCR.

Application of the current single conidium identification method is not limited to the amplification of multiple copies of rDNA sequences. Our previous work revealed that a number of transcripts 
in single conidia of the barley powdery mildew infecting the coleoptile epidermis are potential targets for in situ cDNA synthesis (14). Our micro-needle techniques enabled the removal of cellular contents from target single cells of plants and the subsequent amplification of the involved transcripts by reverse transcription (RT)-PCR/nested PCR and multiplex RT-PCR/nested PCR $(7,30)$. This work indicated that RT-PCR/nested PCR was highly sensitive and able to detect transcripts produced constitutively, and multiplex RT-PCR/nested PCR, which used two pairs of PCR primers, allowed a precise evaluation of inducible gene expression by simultaneously amplifying the transcripts of constitutive and inducible genes, or by detecting sole amplification of the constitutive gene transcripts. Using a micropipette with a highfidelity digital microscope, we have attempted to monitor gene expression in individual conidia on leaf surfaces. To our knowledge, this is the first report to describe the identification and detection of gene expression from single conidia on leaves using direct PCR.

\section{MATERIALS AND METHODS}

Digital microscopic observation and single conidium manipulation. One-month-old seedlings of tomato (Lycopersicon esculentum Mill. cv. Moneymaker) grown in a greenhouse were used in the present study. Healthy leaves without signs of fungal infection were selected at random from tomato seedlings and directly observed with an objective zoom lens (MX-2525CS,

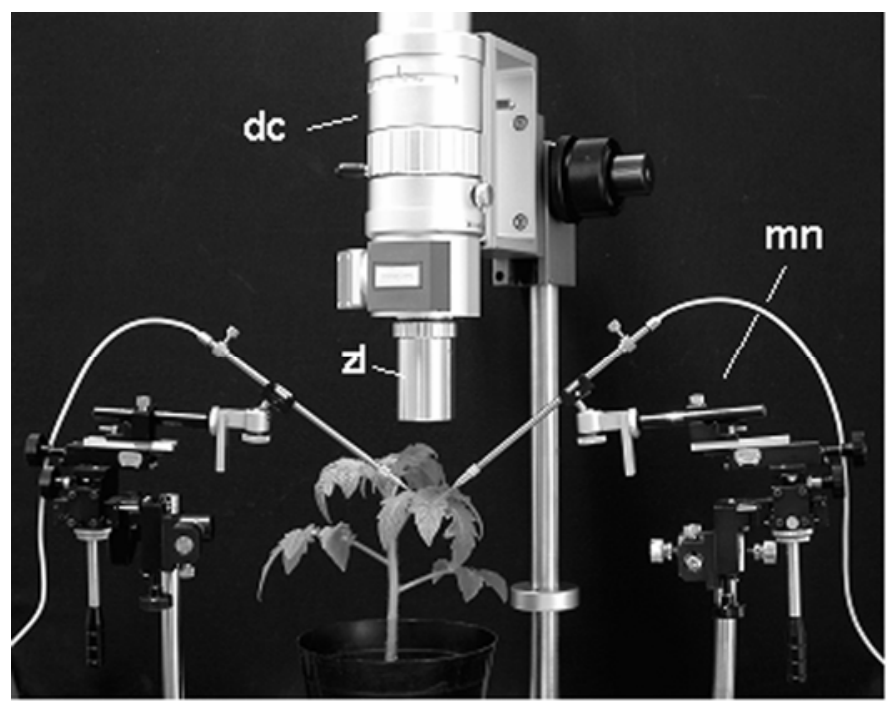

Fig. 1. Digital microscope used for directly observing powdery mildew fungi on untreated tomato leaves. Leaves were directly observed with a zoom lens (zl) of a digital microscope (dc). Individual germinated conidia were removed from leaves with a glass pipette linked to a manipulator $(\mathrm{mn})$ of the microscope.

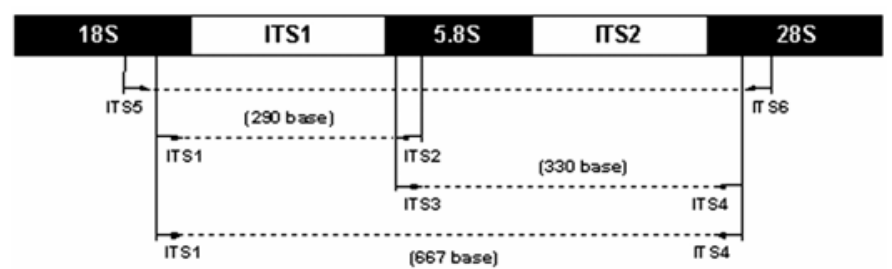

Fig. 2. Four primer pairs used for polymerase chain reaction (PCR) amplification of 5.8S rDNA and internal transcribed spacer regions (ITS1 and ITS2). ITS1 to ITS5 primers were universal primers designed by White et al. (32), and ITS6 primer was constructed in the present study. The primer pair ITS5-ITS6 was used for conventional PCR in the first step of target sequence amplification, and pairs ITS1-ITS2, ITS3-ITS4, or ITS1-ITS4 were used in the second step for the nested PCR. $\times 250$ to $\times 2,500)$ of a high-fidelity digital microscope $(\mathrm{KH}-2700$; HIROX, Tokyo, Japan) (Fig. 1). Digitized images of the conidia were obtained with a 1/2" Interline Transfer CCD camera (HIROX), viewed on a computer display, and manipulated with Adobe Photoshop software (version 5.0) (Adobe, San Jose, CA) according to the method described previously (18). To obtain single propagules, conidia forming appressorial germ tubes on leaves were picked up singly with an autoclaved glass needle linked with a manipulator (Narishige, Tokyo, Japan) on the digital microscope (Fig. 1) and transferred to $15 \mu \mathrm{l}$ of a PCR solution in a $200-\mu \mathrm{l}$ microcentrifuge tube for amplification of the entire $5.8 \mathrm{~S}$ rDNA/ITS region.

ITS sequence amplification by PCR/nested PCR for single conidia. The PCR solution contained the Taq-PCR reaction mixture $(15 \mu \mathrm{l})$ comprising $1.5 \mathrm{mM} \mathrm{MgCl} 2,800 \mu \mathrm{M}$ dNTPs, $0.2 \mu \mathrm{M}$ primers, and 2.5 units of Taq DNA polymerase (Taq PCR Master Mix Kit; Qiagen, Tokyo, Japan). Four pairs of primers (ITS5ITS6, ITS1-ITS4, ITS1-ITS2, and ITS3-ITS4) were used to cover the entire 5.8S rDNA/ITS region (Fig. 2). The primers ITS1 to ITS5 were designed by White et al. (32), and ITS6 was newly constructed on the basis of rDNA sequence of Oidium sp. MUMH66 (AB032483) in the present study (Table 1). The primer pair ITS5-ITS6 was first used for primary PCR (first round of PCR), and the internal primer pairs ITS1-ITS4, ITS1-ITS2, and ITS3-ITS4 for the subsequent nested PCR (second round of PCR). The first round of PCR was performed according to the following protocol: preheating at $95^{\circ} \mathrm{C}$ for 2 min and 30 cycles of denaturing $\left(95^{\circ} \mathrm{C}, 1 \mathrm{~min}\right)$, annealing $\left(55^{\circ} \mathrm{C}, 1 \mathrm{~min}\right)$, and extension $\left(72^{\circ} \mathrm{C}, 1 \mathrm{~min}\right)$ followed by a final extension cycle of $2 \mathrm{~min}$ at $72^{\circ} \mathrm{C}$. The subsequent nested PCR was initiated by mixing $1 \mu \mathrm{l}$ of the first round amplification with $49 \mu \mathrm{l}$ of the previously described first round amplification mixture using the nested primers at a concentration of $0.2 \mu \mathrm{M}$ and cycled under the same protocol with a $60^{\circ} \mathrm{C}$ annealing temperature.

Sequence determination. The amplified DNA was electrophoresed in $1.5 \%$ agarose gel, and the DNA band was excised from the gel and ligated into a pGEM-T easy vector (host bacteria, Escherichia coli DH5 $\alpha$ ) for nucleotide sequencing (Promega, Madison, WI). The nucleotide sequence of the amplified region was determined using a Big Dye Terminator Cycle Sequencing Ready Reaction Kit (Applied Biosystems, Tokyo, Japan) on an ABI Prism 310 Genetic Analyzer (Perkin Elmer Applied Biosystems, Tokyo, Japan) in the Pharmaceutical Research and Technology Institute, Kinki University, Japan. Sequence data of ITS1-ITS2 and ITS3-ITS4 fragments were confirmed with those of ITS1-ITS4 fragment, because both covered the entire $5.8 \mathrm{~S}$ rDNA/ITS region (Fig. 2).

The sequence data from 28 single conidia were classified into two types on the basis of their sequence homology and deposited

TABLE 1. Primers used in this study

\begin{tabular}{|c|c|c|}
\hline PCR targets & Primers & Primer sequences \\
\hline rDNA/ITS & $\begin{array}{l}\text { ITS- } 1^{\mathrm{a}} \\
\text { ITS-2 } \\
\text { ITS- } 3^{\mathrm{a}} \\
\text { ITS-4a } \\
\text { ITS-5 } \\
\text { ITS-6 }\end{array}$ & $\begin{array}{l}\text { 5'-TCCGTAGGTGAACCTGCGG-3' } \\
\text { 5'-GCTGCGTTCTTCATCGATGC-3' } \\
\text { 5'-GCATCGATGAAGAACGCAGC-3' } \\
\text { 5'-TCCTCCGCTTATTGATATGC-3' } \\
\text { 5'-GGAAGTAAAAGTCGTAACAAGG-3' } \\
\text { 5'-AGGTAATCCCGGTTGGTTTC-3' }\end{array}$ \\
\hline TUB2-ol & $\begin{array}{l}\text { tbRT-1 } \\
\text { tbRT-2 } \\
\text { tbN-1 } \\
\text { tbN-2 }\end{array}$ & $\begin{array}{l}\text { 5'-ATTTACAGACCGGTCAATGC-3' } \\
\text { 5'-GGTCTGAATAGCTGGCCAAA-3' } \\
\text { 5'-GGTGAGCATGGACTTGATGG-3' } \\
\text { 5'-GGCTCCAAGTCGACGAGAAC-3' }\end{array}$ \\
\hline CUT1-ol & $\begin{array}{l}\text { cuRT-1 } \\
\text { cuRT-2 } \\
\text { cuN-1 } \\
\text { cuN-2 }\end{array}$ & $\begin{array}{l}\text { 5'-ATGCCATTGGCGAAGATAAG-3' } \\
\text { 5'-TACAGAGCTTGGCGAGACCT-3' } \\
\text { 5'-TTGCTGTGCAGGGTGTACAAT-3' } \\
\text { 5'-ATAATTGGGCGGCATTGTGT-3' }\end{array}$ \\
\hline
\end{tabular}

a Primers described by White et al. (32). 
with the DNA databank of Japan (DDBJ). Genetyx-Mac software (version 11.2, sequence analysis software package, Genetyx Inc., Tokyo, Japan) was used for sequence analysis and the BLAST software was accessed through the National Center for Biotechnology Information (Bethesda, MD).

Inoculation of single conidia of tomato powdery mildew into tomato leaves. Conidia of tomato powdery mildew (O. neolycopersici isolate KTP-01) were maintained on leaves of onemonth-old seedlings of tomato as previously reported (11). Newly produced conidia were singly transferred onto fresh tomato leaves with the micromanipulator of a digital microscope. Ungerminated (immediately after the transfer) and germinated conidia ( $5 \mathrm{~h}$ after transfer) were removed from the leaves and used for PCR analyses.

Transcript amplification by RT-PCR/nested PCR from single conidia. Two genes, TUB2-ol (AB204904) and CUT1-ol (AB204905), were selected as PCR targets. These two genes were obtained as homologs to $\beta$-tubulin 2 (TUB2) (X51326) and cutinase 1 (CUT1) genes (AF326784) of barley powdery mildew (Blumeria graminis f. sp. hordei). The primers were artificially constructed to amplify internal transcript regions by RT-PCR followed by nested PCR. The primer pairs used for RT-PCR and nested PCR were tbRT-1/tbRT-2 and tbN-1/tbN-2 for TUB2-ol and cuRT-1/cuRT-2 and cuN-1/cuN-2 for CUT1-ol (Table 1). The single conidia removed from leaves were directly placed into $15 \mu \mathrm{l}$ of RT-PCR buffer containing $0.2 \mu \mathrm{M}$ of each primer, $2.5 \mathrm{mM}$ dNTPs, $25 \mathrm{mM} \mathrm{Mn}(\mathrm{OAc})_{2}, 20$ units of RNase inhibitor, and 5.0 units of rTth DNA polymerase (RT-PCR High-Plus-Kit, Toyobo) in a $200-\mu$ l Eppendorf tube. The PCR was performed with reverse transcription at $50^{\circ} \mathrm{C}$ for $30 \mathrm{~min}$, preheating at $95^{\circ} \mathrm{C}$ for $2 \mathrm{~min}$, and then 30 cycles with denaturing at $95^{\circ} \mathrm{C}$ for $1 \mathrm{~min}$, annealing at $58^{\circ} \mathrm{C}$ for $1 \mathrm{~min}$, and extension at $72^{\circ} \mathrm{C}$ for $2 \mathrm{~min}$, for both genes. A 1- $\mu \mathrm{l}$ aliquot of the reaction mixture was mixed with $49 \mu \mathrm{l}$ of the nested PCR buffer containing $0.2 \mu \mathrm{M}$ primers, $1.5 \mathrm{mM} \mathrm{MgCl}_{2}, 800 \mu \mathrm{M}$ dNTPs, and 2.5 units of Taq DNA polymerase (Taq PCR Master Mix Kit, Qiagen). Nested PCR amplification conditions for both genes were preheating at $95^{\circ} \mathrm{C}$ for $2 \mathrm{~min}, 30$ cycles of denaturing at $95^{\circ} \mathrm{C}$ for $1 \mathrm{~min}$, annealing at $60^{\circ} \mathrm{C}$ for $1 \mathrm{~min}$, and extension at $72^{\circ} \mathrm{C}$ for $2 \mathrm{~min}$. Electrophoresis and nucleotide sequence determination of the final products were as previously described.

Multiplex RT-PCR/nested PCR. The constitutively expressed gene TUB2-ol was used as a control for multiplex RT-PCR/nested amplification. Single conidia were transferred to $15 \mu \mathrm{l}$ of the reaction buffer described above, and following the first round of amplification containing two pairs of the RT-PCR primers (tbRT$1 /$ tbRT-2 and cuRT-1/cuRT-2), $1 \mu \mathrm{l}$ of the reaction mixture was mixed with $24 \mu \mathrm{l}$ of the reaction mix containing two pairs of the nested PCR primers (tbN-1/tbN-2 and cuN-1/cuN-2).

\section{RESULTS}

Digital microscopic assay for conidial distribution on tomato leaves. Natural infection by the powdery mildew fungi was observed on healthy leaves (800 leaves) selected at random from 400 tomato seedlings grown in a greenhouse. On 421 of these leaves, powdery mildew conidia that had formed appressorial germ tubes were detected. These conidia were examined for their length or shape of germ tubes. The germ tube length was measured for all conidia detected, and each conidium was plotted on the basis of germ tube length (Fig. 3). While their germ tube lengths overlapped, there were two distinguishable groups for the conidial population germinated on tomato leaves; one group formed a secondary germ tube from the short, primary germ tube (A-type conidia) (Fig. 4A), and the other formed a linear appressorial germ tube (B-type conidia) (Fig. 4B and C). A-type conidial germ tube lengths were broadly distributed from $\approx 20$ to $75 \mu \mathrm{m}$ without a well-defined peak in frequency (open column in
Fig. 3), whereas the germ tube lengths of B-type conidia were skewed into a narrow major peak at $\approx 15$ and a minor broad peak at $\approx 45 \mu \mathrm{m}$ (closed column). Most of the germ tubes for B-type conidia were less than $20 \mu \mathrm{m}$ and had secondary hyphae elongating from the conidia (Fig. 4D), as reported previously for the conidia of $O$. neolycopersici (11), but B-type conidia without secondary hyphae (Fig. 4B) were also detected in this major peak, although the incidence of conidia lacking secondary hyphae was less than $5 \%$ (data not shown). No conidia from the approximately $45 \mu \mathrm{m}$ peak developed secondary hyphae (Fig. 4C).

Removal and identification of single conidia from leaves. Thirty conidia were individually removed from leaf surfaces and nested PCR was used to amplify inner fragments of the 5.8S/ITS region (Table 2; Fig. 5A, lanes 2 to 4 ). There was no detectable amplification product following the first round standard PCR (lane 5). PCR-amplified fragments were obtained from 10 A-type and 18 B-type conidia (Table 2); the rate of successful PCR amplification was $93.3 \%$ (28/30 conidia). The nucleotide sequences were identical within the conidial groups. A BLAST analysis indicated that the entire $5.8 \mathrm{~S}$ rDNA/ITS region of the Atype conidia (AB167523 assigned in DDBJ) was identical to the red clover powdery mildew fungus Erysiphe trifolii (AB015913) (25) and B-type conidia (AB163927 and AB163926 assigned in DDBJ) were identical with either $E$. trifolii or isolates of $O$. neolycopersici (AB094991 and AF229019) (11,12). B-type conidia in the $15 \mu \mathrm{m}$ peak corresponded to $O$. neolycopersici and conidia in the $45 \mu \mathrm{m}$ peak had the $E$. trifolii sequence. In addition, the nested PCR method enabled the identification of the B-type conidial overlap (germ tube length of 20 to $30 \mu \mathrm{m}$ ) of the two peaks (Table 2).

Amplification of mature mRNAs in individual conidia by RT-PCR/nested PCR. Figure 5B shows the products of RT$\mathrm{PCR} /$ nested PCR from individual ungerminated and germinated conidia that were removed from leaves. Target sequences could be detectably amplified by the RT-PCR/nested PCR system. The amplified products with tbRT-1/tbRT-2 and tbN-1/tbN-2 (for TUB2-ol gene transcripts) were detected in both ungerminated and germinated conidia (Fig. 5B, lanes 2 and 3), while the products with cuRT-1/cuRT-2 and cuN-1/cuN-2 (for CUT1-ol) were detected only in germinated conidia (lanes 4 and 5). Successful amplification of TUB2-ol transcripts was achieved in 11 of 12 ungerminated conidia and in all germinated conidia, whereas CUT1-ol transcripts were amplified in 13 of 15 germinated

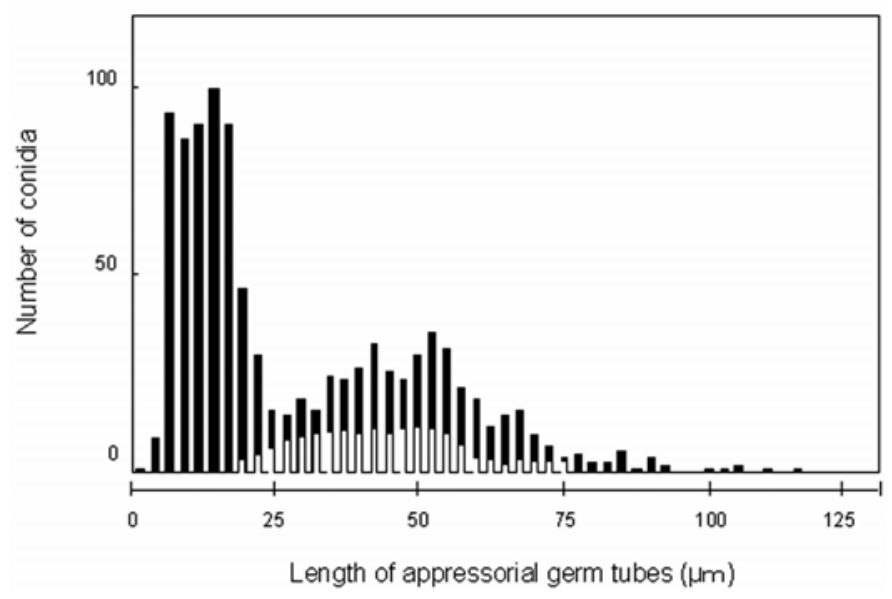

Fig. 3. Distribution of conidial germ tube lengths from naturally infected leaves of tomato grown in a greenhouse. There were two distinguishable groups in the conidial population on tomato leaves; one group formed secondary germ tubes from the short, primary germ tube (A-type conidia) (white column), and the other group formed linear appressorial germ tubes (B-type conidia) (black column). A-type forms a broad normal distribution, and B-type forms a skewed distribution with sharp, broad peaks that represent two overlapping normal distributions. 
conidia ( 0 of 12 ungerminated conidia). All amplified fragments (34 total) were sequenced and confirmed to be coincident with intron-eliminated sequences of TUB2-ol or CUT1-ol (data not shown).

Multiplex RT-PCR/nested PCR for evaluation of successful PCR performance. No electrophoretic band was detected with RT-PCR/nested PCR for the CUT1-ol gene from ungerminated conidia (Fig. 5B, lane 4). To be certain that absence of the band was not due to technical errors, we simultaneously amplified transcripts using the mixed primers for multiplex RT-PCR/nested PCR of TUB2-ol and CUT1-ol genes. In this experiment, the constitutively detectable $T U B 2-o l$ gene was used as an indicator for successful amplification. The multiplex RT-PCR/nested PCR method yielded one intense band of TUB2-ol transcripts from 15 of 15 ungerminated conidia (Fig. 5B, lane 6) and two bands of TUB2-ol and CUT1-ol transcripts in 13 of 14 germinated conidia (lane 7). These results were comparable to the data of RT-PCR/ nested PCR, indicating that CUT1-ol was expressed at germination, but not in ungerminated conidia.

\section{DISCUSSION}

Light microscopic observation of decolored and aniline bluestained leaf specimens enabled clear detection of epiphytic powdery mildew fungi (23), but these fungi could not be micromanipulated because specimens were covered with a glass coverslip. With the digital microscope that was used in this investigation, living fungi can easily be removed from leaf surfaces directly at high magnification $(\times 1,000)$ and high resolution without being covered with a coverslip or mountant. This high magnification was essential to detect conidia on leaves, unattainable with conventional stereomicroscopes with lower limits of magni- fication. Conidia could be removed at different stages of development, using a glass pipette linked with a manipulator of this microscope. The method also enables us to dispense chemicals to decolorize leaves or stain the fungus, which could inhibit enzymes essential for the PCR. Bindslev et al. (2) used in situ PCR amplification to detect a gene in the barley powdery mildew fungus, using peeled epidermis of inoculated barley leaves. However, peeling the epidermis from inoculated leaves of many plant species, including tomato and red clover, is not always easy or effective. From this point of view, the digital microscopic manipulation combined with the PCR techniques may be useful for studying other epiphytic fungal pathogens regardless of the plants to be tested.

The first step essential for the PCR was effective disruption of fungal cells. Bindslev et al. (2) partially digested fungal cells with a cell wall-degrading enzyme (zymolyase) containing chitinases to introduce primers, nucleotides, and polymerase into the cells for in situ PCR. Walsh et al. (31) reported successful fungal disruption with heating prior to PCR. Using Walsh's method based on chelex-trapping of extracted DNA, we also successfully extracted DNA in another trial (11). The present result indicates that pretreatment with cell wall-digesting enzymes is not always essential for disrupting fungal cells, at least in the present PCR system using single conidia.

The present system involved nested PCR to amplify DNA sequences from single infection propagules of the powdery mildew fungus. For this purpose, two sets of the primers (external and internal primer pairs to the target sequences) were designed according to the description of Pepper and Dowd (20); the first was the external primer pair for amplification of a trace quantity of target sequences by PCR, and the second was the internal primer pairs for subsequent amplification of the target sequences
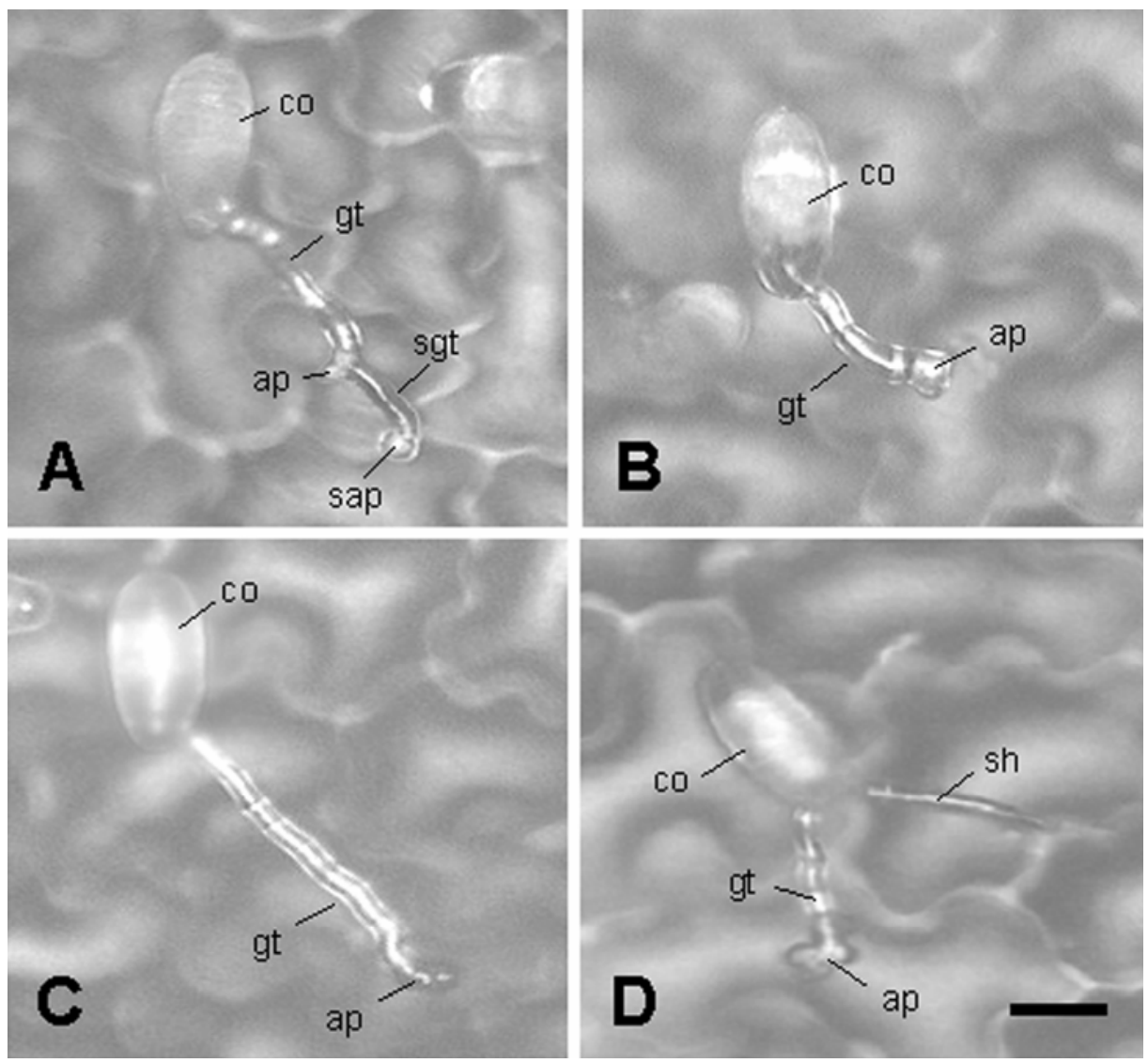

Fig. 4. Digital micrographs of powdery mildew conidia forming appressorial germ tubes on naturally infected tomato leaves. A-type conidia formed short appressorial germ tubes followed by secondary appressorial germ tubes (A). B-type conidia formed linear germ tubes (B and C). Some of B-type conidia produced secondary hyphae from conidia, as shown in $\mathbf{D}$. Bar $=10 \mu \mathrm{m}$. Abbreviations: co, conidium; gt, germ tube; ap, appressorium; sh, secondary hypha; sgt, secondary germ tube; and sap, secondary appressorium. 
by nested PCR at a higher annealing temperature to permit amplification only by these primer pairs. Using the primary PCR/nested PCR method, Llop et al. (13) successfully detected a specific DNA fragment of plasmid PEA29 present in trace amounts of

TABLE 2. Determination of internal transcribed spacer (ITS) sequence in single conidia with different germ tube length by nested polymerase chain reaction $(\mathrm{PCR})$

\begin{tabular}{|c|c|c|c|}
\hline Conidia tested & $\begin{array}{l}\text { Length of } \\
\text { germ tube }\end{array}$ & $\begin{array}{c}\text { Type of } \\
\text { germinating } \\
\text { conidia }^{\mathrm{a}}\end{array}$ & $\begin{array}{c}\text { Type of } \\
\text { ITS sequence } \\
\text { determined }^{\mathrm{b}}\end{array}$ \\
\hline 1 & 112.5 & B & $\mathrm{Et}$ \\
\hline 2 & 108.5 & B & $\mathrm{Et}$ \\
\hline 3 & 88 & B & $-^{\mathrm{c}}$ \\
\hline 4 & 80.5 & B & $\mathrm{Et}$ \\
\hline 5 & 75 & A & $\mathrm{Et}$ \\
\hline 6 & 72 & B & $\mathrm{Et}$ \\
\hline 7 & 71.5 & A & $\mathrm{Et}$ \\
\hline 8 & 70 & B & $\mathrm{Et}$ \\
\hline 9 & 69.5 & B & Et \\
\hline 10 & 65 & B & Et \\
\hline 11 & 60.5 & B & Et \\
\hline 12 & 54 & A & Et \\
\hline 13 & 53.5 & A & Et \\
\hline 14 & 52 & B & Et \\
\hline 15 & 50 & A & Et \\
\hline 16 & 47.5 & A & Et \\
\hline 17 & 25 & B & On \\
\hline 18 & 24 & B & $\mathrm{Et}$ \\
\hline 19 & 23.5 & A & $\mathrm{Et}$ \\
\hline 20 & 22 & B & On \\
\hline 21 & 21 & A & $\mathrm{Et}$ \\
\hline 22 & 20.5 & B & On \\
\hline 23 & 18 & B & On \\
\hline 24 & 15.5 & A & $\mathrm{Et}$ \\
\hline 25 & 13 & B & On \\
\hline 26 & 12.5 & B & On \\
\hline 27 & 11 & B & On \\
\hline 28 & 10 & B & On \\
\hline 29 & 8 & B & - \\
\hline 30 & 6.5 & B & On \\
\hline
\end{tabular}

a A, A-type conidia; B, B-type conidia. A-type conidia formed short appressorial germ tubes followed by secondary appressorial germ tubes. B-type conidia formed linear germ tubes.

${ }^{\mathrm{b}}$ Et, Erysiphe trifolli; On, Oidium neolycopersici.

c The product was not obtained because of unsuccessful PCR amplification. bacterial samples (Erwinia amylovora). In the present application, this method was sensitive enough to amplify the entire $5.8 \mathrm{~S}$ rDNA/ITS region from a single germinated conidium. DNA fragments were amplified in detectable amounts when nested amplification was performed, but not with just a single round of amplification. The use of nested PCR was essential because of the small quantity of primary PCR product obtained from solitary germinating propagules. This technique successfully amplified the target sequence in $93.3 \%$ of the conidia tested.

Phylogenetic relationships among powdery mildew fungi have been characterized by analyzing ITS sequence of rDNA. There is a good correlation between the morphological classification system for the powdery mildews described by Cook et al. (5) and the ITS sequence-based classification developed by Saenz and Taylor (22). Moreover, enough sequence data for the ITS regions of rDNA have been accumulated to confirm species identification of powdery mildew pathogens $(8,17,22,24,26)$ including $O$. neolycopersici (10-12) and E. trifolii (25). Using these data to characterize single conidia on leaves, we found that the nucleotide sequences from the conidia were completely coincident with those of $O$. neolycopersici or E. trifolii. In the present study, tomato seedlings were grown in the greenhouse where tomato powdery mildew frequently occurred year round (16). These results indicate that conidia of both tomato powdery mildew (O. neolycopersici) and red clover powdery mildew (E. trifolii) were produced from natural sources of inoculum. The present study clearly demonstrated natural infection of tomato leaves from morphologically indistinguishable conidia of both pathogenic (O. neolycopersici) and nonpathogenic (E. trifolii) powdery mildews. The method we report here was effective in distinguishing between the conidia with the same mean length of germ tubes as well as between conidia with different germ tube lengths (Table 2).

We were also able to apply the single conidium PCR methodology to the detection of mature transcripts at the pre- and postgermination stages of tomato powdery mildew conidia. Despite the importance of early events in invasion and infection, there has been no report on the genes expressed during the germination stage of this pathogen. However, an expressed sequence tag (EST) database has been constructed for barley powdery mildew $(3,27$, 28), and its sequence data are available (Phytopathogenic Fungi and Oomycete EST Database; Swindon, UK). Of the genes that

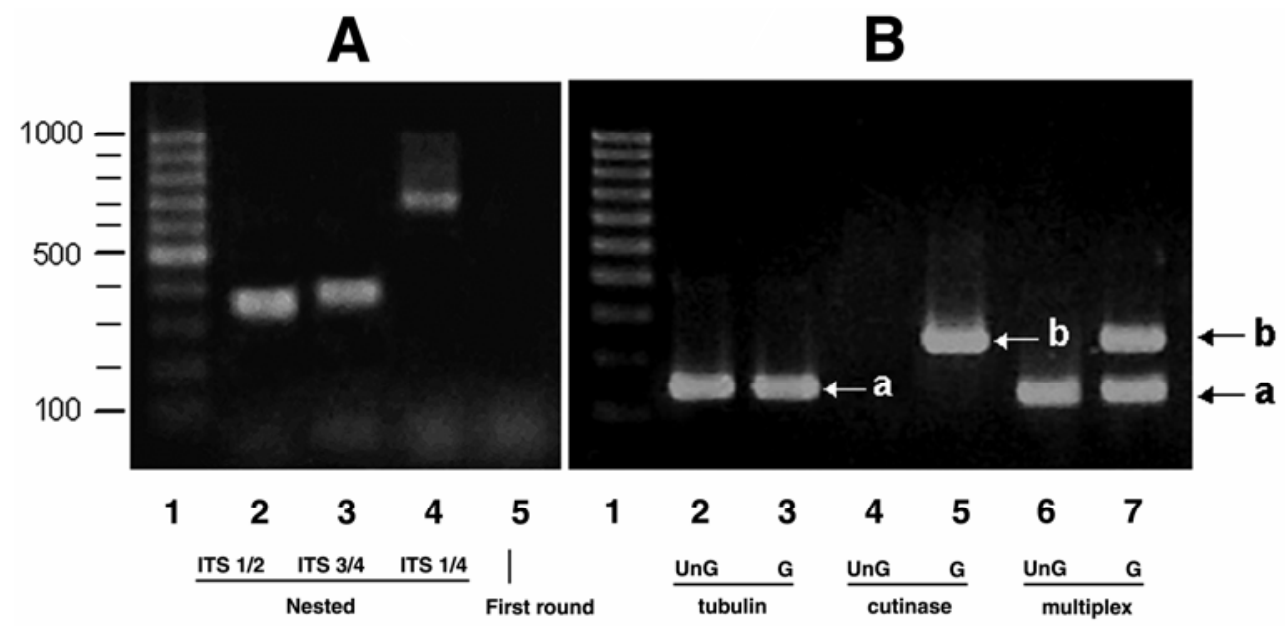

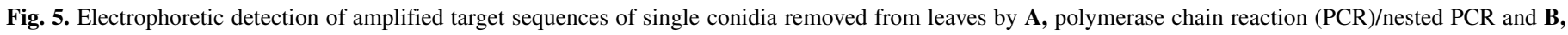

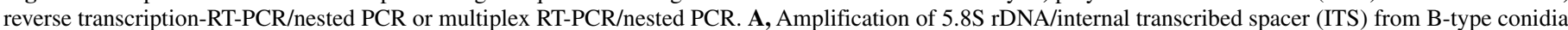

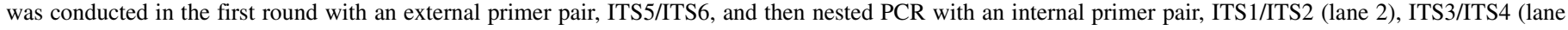

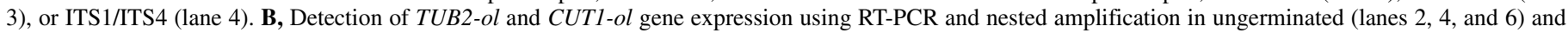

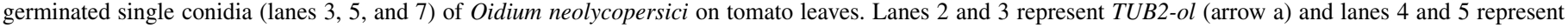

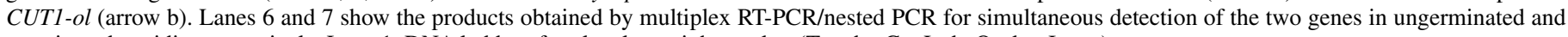
germinated conidia, respectively. Lane 1, DNA ladder of molecular weight marker (Toyobo Co. Ltd., Osaka, Japan). 
have been studied in detail in $B$. graminis, the TUB2 gene for $\beta$ tubulin biosynthesis and CUT1 gene for cutinase production are particularly useful because TUB2 is constitutively expressed (33), making it an excellent transcriptional control and cutinase was induced in germinated conidia of tomato powdery mildew (9), grapevine powdery mildew (21), and barley powdery mildew $(6,19)$. Because of the high nucleotide sequence homology (including introns, TUB2 and TUB2-ol are 98\% identical, CUT1 and CUT1-ol are $99.0 \%$ identical, data not shown), we were able to use homologs TUB2-ol and CUT1-ol of tomato powdery mildew. For detecting transcripts of these genes from individual conidia on leaves, RT-PCR/nested PCR was used instead of PCR/nested PCR. In both PCR systems, nested PCR was essential for amplification of the target sequences. Evidently, nested PCR was dependent on effective amplification of target sequences by PCR or RT-PCR performed in the initial round. In the present study, the experimental protocols applied (scale and number of PCR cycles) were identical for both PCR methods. The intensity of the electrophoretic bands of amplified fragments was similar in both samples of RT-PCR/nested PCR and PCR/nested PCR. This implies that RT-PCR produced cDNAs from mature mRNAs at levels comparable to DNA amplified from genomic 5.8S rDNA/ITS by PCR. Moreover, successful RT-PCR/nested PCR was confirmed by detecting mature transcripts from single conidia, and a lack of expression of CUT1-ol in ungerminated conidia was confirmed by the multiplex RT-PCR/nested PCR analysis on the basis of simultaneous detection of TUB2-ol. Thus, the present study demonstrates that the expression of $T U B 2-o l$ was apparently constitutive, or at least present during both of the stages tested, and CUT1-ol was induced by contact with the leaf surface or during germination.

To our knowledge, the present study is the first report on distinguishing morphologically similar conidia on the same leaf. This approach was dependent on PCR techniques using single conidia manipulated under a high-fidelity digital microscope. Current methods for determining the identification of powdery mildew on leaves are based on mass collection of conidia from infected leaves and analysis of ITS sequences. In these methods, however, plant materials, such as leaf trichomes (unpublished data) or leaf surface-inhabiting microorganisms (26), are frequent contaminants. In contrast, the present method minimized contamination since naked single conidia were picked from the tomato leaf surface. In addition to PCR/nested PCR, RT-PCR/nested PCR was applicable for single conidia with similar experimental protocols and with similar sensitivity and reproducibility. Thus, the present study provides a molecular method for monitoring gene expression in germinating conidia on leaf surface.

\section{ACKNOWLEDGMENTS}

We thank B. E. Hazen for providing helpful comments and suggestion to revise the manuscript.

\section{LITERATURE CITED}

1. Agrios, G. N. 1988. How plants defend themselves against pathogens. Pages 97-115 in: Plant Pathology. Academic Press, New York.

2. Bindslev, L., Oliver, R. P., and Johansen, B. 2002. In situ PCR for detection and identification of fungal species. Mycol. Res. 106:277-279.

3. Both, M., Eckert, S. E., Csukai, M., Muller, E., Dimopoulos, G., and Spanu, P. D. 2005. Transcript profiles of Blumeria graminis development during infection reveal a cluster of genes that are potential virulence determinants. Mol. Plant-Microbe Interact. 18:125-133.

4. Brown, J. K. M., and Hovmeøller, M. S. 2002. Aerial dispersal of pathogens on the global and continental scales and its impact on plant disease. Science 297:537-541.

5. Cook, R. T. A., Inman, A. J., and Billings, C. 1997. Identification and classification of powdery mildew anamorphs using light and scanning electron microscopy and host range data. Mycol. Res. 101:975-1002.

6. Francis, S. A., Dewey, F. M., and Gurr, S. J. 1996. The role of cutinase in germling development and infection by Erysiphe graminis f. sp. hordei. Physiol. Mol. Plant Pathol. 49:201-211.
7. Fujita, K., Matsuda, Y., Wada, M., Hirai, Y., Mori, K., Moriura, N., Nonomura, T., Kakutani, K., and Toyoda, H. 2004. Powdery mildew pathogens can suppress the chitinase gene expression induced in detached inner epidermis of barley coleoptile. Plant Cell Rep. 23:504-511.

8. Hirata, T., and Takamatsu, S. 1996. Nucleotide sequence diversity of rDNA internal transcribed spacers extracted from conidia and cleistothecia of several powdery mildew fungi. Mycoscience 37:283-288.

9. Jones, H., Whipps, J. M., and Gurr, S. J. 2001. The tomato powdery mildew fungus Oidium neolycopersici. Mol. Plant Pathol. 2:303-309.

10. Jones, H. E., Whipps, J. M., Thomas, B. J., Carver, T. L. W., and Gurr, S. J. 2000. Initial events in the colonisation of tomatoes by Oidium lycopersici, a distinct powdery mildew fungus of Lycopersicon species. Can. J. Bot. 78:1361-1366.

11. Kashimoto, K., Matsuda, Y., Matsutani, K., Sameshima, T., Kakutani, K., Nonomura, T., Okada, K., Kusakari, S., Nakata, K., Takamatsu, S., and Toyoda, H. 2003. Morphological and molecular characterization for a Japanese isolate of tomato powdery mildew Oidium neolycopersici and its host range. J. Gen. Plant Pathol. 69:176-185.

12. Kiss, L., Cook, R. T. A., Saenz, G. S., Cunnington, J. H., Takamatsu, S., Pascoe, I., Bardin, M., Nicot, P. C., Sato, Y., and Rossman, A. Y. 2001. Identification of two powdery mildew fungi, Oidium neolycopersici sp. nov. and $O$. lycopersici, infecting tomato in different parts of the world. Mycol. Res. 105:684-697.

13. Llop, P., Bonaterra, A., Penalver, J., and Lopez, M. M. 2000. Development of a highly sensitive nested-PCR procedure using a single closed tube for detection of Erwinia amylovora in asymptomatic plant material. Appl. Environ. Microbiol. 66:2071-2078.

14. Matsuda, Y., Toyoda, H., Kurita, A., and Ouchi, S. 1997. In situ PCR technique based on pricking microinjection for cDNA cloning in single cells of barley coleoptile and powdery mildew pathogen. Plant Cell Rep. 16:612-618.

15. Matsuda, Y., Toyoda, H., Morita, M., Ikeda, S., Tamai, T., Nishiguchi, T., and Ouchi, S. 1994. A novel method for in situ hybridization in fungal cells based on pricking micro-injection of photobiotin labeled probes. J. Phytopathol. 141:133-142.

16. Matsuda, Y., Kashimoto, K., Takikawa, Y., Aikami, R., Nonomura, T., and Toyoda, H. 2001. Occurrence of new powdery mildew on greenhouse tomato cultivars. J. Gen. Plant Pathol. 67:294-298.

17. Mori, Y., Sato, Y., and Takamatsu, S. 2000. Evolutionary analysis of the powdery mildew fungi using nucleotide sequences of the nuclear ribosomal DNA. Mycologia 92:74-93.

18. Oichi, W., Matsuda, Y., Sameshima, T., Nonomura, T., Kakutani, K., Nishimura, H., Kusakari, S., and Toyoda, H. 2004. Consecutive monitoring for conidiogenesis by Oidium neolycopersici on tomato leaves with a high-fidelity digital microscope. J. Gen. Plant Pathol. 70:318-321.

19. Pascholati, S. F., Yoshioka, H., Kunoh, H., and Nicholson, R. L. 1992. Preparation of the infection court by Erysiphe graminis f. sp. hordei: Cutinase is a component of the conidial exudates. Physiol. Mol. Plant Pathol. 41:53-59.

20. Pepper, I. L., and Dowd, S. E. 2002. PCR applications for plant and soil microbes. Pages 573-582 in: Manual of Environmental Microbiology. C. J. Hurst, R. L. Crawford, G. R. Knudsen, M. J. McInerney, and L. D. Stetzenbach, eds. ASM Press, Washington DC.

21. Rumbolz, J., Kassemeyer, H. H., Steinmetz, V., Deising, H. B., Mendgen, K., Mathys, D., Wirtz, S., and Guggenheim, R. 2000. Differentiation of infection structures of the powdery mildew fungus Uncinula necator and adhesion to the host cuticle. Can. J. Bot. 78:409-421.

22. Saenz, G. S., and Taylor, J. W. 1999. Phylogeny of the Erysiphales (powdery mildews) inferred from internal transcribed spacer ribosomal DNA sequences. Can. J. Bot. 77:150-168.

23. Sameshima, T., Kashimoto, K., Kida, K., Matsuda, Y., Nonomura, T., Kakutani, K., Nakata, K., Kusakari, S., and Toyoda, H. 2004. Cytological events in tomato leaves inoculated with conidia of Blumeria graminis f. sp. hordei and Oidium neolycopersici KTP-01. J. Gen. Plant Pathol. 70:7-10.

24. Takamatsu, S., Hirata, T., and Sato, Y. 1998. Phylogenetic analysis and predicted secondary structures of the rDNA internal transcribed spacers of the powdery mildew fungi (Erysiphaceae). Mycoscience 39:441-453.

25. Takamatsu, S., Hirata, T., Sato, Y., and Nomura, Y. 1999. Phylogenetic relationships of Microsphaera and Erysiphe section Erysiphe (powdery mildews) inferred from the rDNA ITS sequences. Mycoscience 40:259268.

26. Takamatsu, S., and Kano, Y. 2001. PCR primers useful for nucleotide sequencing of rDNA of the powdery mildew fungi. Mycoscience 42:135-139.

27. Thomas, S. W., Glaring, M. A., Rasmussen, S. W., Kinane, J. T., and Oliver, R. 2002. Transcript profiling in the barley mildew pathogen Blumeria graminis by serial analysis of gene expression (SAGE). Mol. Plant-Microbe Interact. 15:847-856.

28. Thomas, S. W., Rasmussen, S. W., Glaring, M. A., Rouster, J. A., Christansen, S. K., and Oliver, R. P. 2001. Gene identification in the 
obligate fungal pathogen Blumeria graminis by expressed sequence Tag analysis. Fungal Genet. Biol. 33:195-211.

29. Toyoda, H., Matsuda, Y., Shoji, R., and Ouchi, S. 1987. A microinjection technique for conidia of Erysiphe graminis f. sp. hordei. Phytopathology 77:815-818.

30. Wada, M., Matsuda, Y., Fujita, K., Nanjo, A., Nishimura, M., Nonomura, T., Kakutani, K., and Toyoda, H. 2004. RT-PCR amplification of mRNAs in nuclei or cytosol of single cells of tomato callus after micropipette extraction. Plant Cell Tissue Org. Cult. 79:109-114.

31. Walsh, P. S., Metzger, D. A., and Higuchi, R. 1991. Chelex 100 as a medium for simple extraction of DNA for PCR-based typing from forensic material. BioTechniques 10:506-513.

32. White, T. J., Bruns, T., Lee, S., and Taylor, J. 1990. Amplification and direct sequencing of fungal ribosomal RNA genes for phylogenetics. Pages 315-322 in: PCR Protocols: A Guide to Methods and Applications. M. A. Innis, D. H. Gelfand, J. J. Sninsky, and T. J. White, eds. Academic Press, San Diego.

33. Zhang, Z., Hall, A., Perfect, E., and Gurr, S. J. 2000. Differential expression of two Blumeria graminis chitin synthase genes. Mol. Plant Pathol. 1:125-138. 